より強度が減少するものではより大をく減少し, 強度が 増加するものではより大をく増加する。

また, 花崗岩と砂岩については, 加熱条件を変化させ て試験を行的たが， $600^{\circ} \mathrm{C}$ に加熱した花崗岩以外はあ

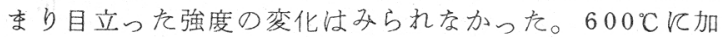
熱した場合の花崗岩は, 昇温速度が小さい在と, 定温保 持時間が長い在ど著しく強度在低下させた。

これらの現象が生じる岩石学的な考察について若干の問 題提起は行えるが，今後検討すべを問題として残されてらる。
参芳文 献

1) В.В.Ржеьский ; Г.Я.Ноьик : Осноы физики горньх Пород , (1964) Р.102

2) Николин В.И.:Прочность некоторьх осадочньк пород при ьысоких температчрах, Нефт.Хо3. 1964 [2] , 14-16

3) Нельничук И.П.; фокееь В.М. : Влчяние температуры Нагреьа и последующего охла ждения на Механические сьоист ьа горных пород , Р азыдка и Охрана Недр.1965[11],28-32

4) 永井他編集: 無機有機工業材料便覧, 東洋経済新報社, 昭和 36 年, 33 頁

\title{
1109 火咨ジェットさく孔機の試作と岩石の熱破壊について
}

東京大学土学部助教授・工博外尾善 次 郎(正会員)

\section{1. えがき}

岩石の破壊には発破に上る方法, 打撃に上る方法, さ らにトンネルマシン等の切削による方法等が用らられて らるが，米国，ソ連等で実用化しだした熱破壊(シェット ピヤサー，サーモドリル）【上る方法がある。筆者は数年前 からサーモドリルの試作とその試験を行なってきた。后添 実用機の域に達したのでその設計メカニズムにつんて報告 し, さらに岩石熱破壊メカニズムの基礎研究として行索っ た理論と実験による熱破壊機構の考察につんて報告する。 火炎シェットは坑内作業には利用でをないが, 坑外での 作業，特に建設関係で広く利用できる。ビルの取壊し等 に利用すればその効果は非常に大をいと期待できる。

2. 火炎ジェットさく孔機（サーモドリル，サーモ カッター)について

第 1 図に示すような, 酸素一ケロシン系によるサーモ ドリルを試作した。これは大別して

(亿) 燃焼室

(ロ) インジェクター

(Py 泠却機構

の3つから成っている。インジェタターから噴出されたケ ロシンと酸素は,燃焼窒内で燃焼し, 超音速火咨シェットと 病らてノスルから噴射される。設計では然烇室内の温度を $3200^{\circ} \mathrm{K}$ とし, 火炎ジットの温度 $2500^{\circ} \mathrm{K}$ 程度, 火炎济 ットの噴射速度は $1800 \mathrm{~m} / \mathrm{sec}($ マッハ5 6) 程度に設計さ れている。燃焼室外周は, 巡睘水に上り冷却せしめ, 巡 環水の水温を $60^{\circ} \mathrm{C}$ 以下机さえるようにしている。設 計には次の諸式を利用した。

さく孔径存dとすると

(1) ケロシン量 $G_{k}=k_{1} d^{2} \quad$ ( $k_{1}$ 壮定数) …(1)

(2) 酸素最 $\quad G_{0}=k_{2} d^{2}$ ( $k_{2}$ 壮定数) … (2)

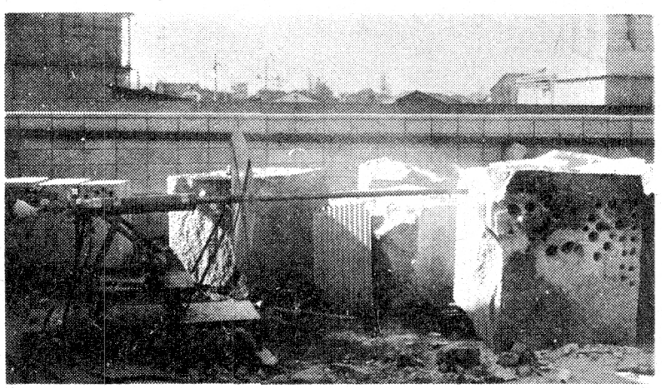

第1図 火资シェットさく孔機
(3) ノズル臨界断面積 $F_{0}=\frac{G_{f}}{\gamma_{c r} v_{c r}}$

$G_{f}=G_{k}+G_{0 x}, \gamma_{c r}:$ ノズル臨界断面積での ガス比重 $\left(\mathrm{kg} / \mathrm{cm}^{3}\right)$

$v_{c r}$ : 速度 $(\mathrm{m} / \mathrm{sec})$

$\gamma_{c r}=\frac{P_{c r}}{R T_{c r}}, P_{c r}=P_{b}\left(\frac{2}{\xi+1}\right)^{\frac{\xi}{\xi-1}}, \xi=\frac{C_{p}}{C_{v}} \cdots$ (4)

$R$ : ガス定数, $P_{b}=5 \mathrm{~kg} / \mathrm{cm}^{2}$ (燃烇室内圧力)

$T_{c r}=\frac{2}{\xi+1} \cdot T_{b}$

(4) ノズル出口断面積 $F_{1}=\frac{G_{f}}{\gamma_{1} v_{1}}$

$\gamma_{1}:$ ノズル出ロでのガス比重

$v_{1}:$ ノズル出口でのガス速度

(5) ノズル長さ $l_{0}=\frac{d_{1}-d_{c r}}{2 \tan \alpha}$

$d_{1}$ : ノズル出口直径, $d_{c r}$ : ノズル臨界断面直径

$\alpha$ : ノズルの開妾角度

(6) ケロシン噴射孔の合計断面積 $\left(F_{k}\right)$

$F_{k}=\frac{G_{k}}{\mu_{k} \sqrt{2 g \Delta P_{k} \gamma_{k}}}$

$\mu_{k}$ : ケロシン流出係数 $(0.51)$

$\Delta P_{k}$ ：ケロシン噴霧ノズルでの圧力降下量

$\gamma_{k}:$ ケロシン比重

(7) 所要巡環冷却水量 $(W)$

$$
W=\frac{Q}{C_{w} \cdot T_{w}}
$$

$C_{w}$ : 水の比熱, $T_{w}$ : 水温 $\left(60^{\circ} \mathrm{C}\right)$

$Q=$ 全水量 $=q \cdot F, F$ : 冷却表面積

$q$ : 燃狫室壁面加出てゆく熱量

巡噮水と接している燃焼室壁面の温度 $\left(T_{C}\right)$ ，

$T_{c}=\frac{q}{\eta}+T_{w}$

ク：壁面から水への熱伝達係数

$\eta=0.023 \frac{\lambda_{w}}{D}\left(\frac{D v_{w} \gamma_{w}}{\mu_{w} g}\right)^{0.8}\left(\frac{\mu_{w} g C_{w}}{\lambda_{w}}\right)^{0.4} \ldots \ldots \ldots \ldots$ (11)

$\lambda_{w}:$ 水の熱伝導率, $D=4 r_{0}$

$\dot{r_{0}}=\frac{S}{l}$ ( $S$ : 水キャナル断面積, $L$ : 周辺長)

$v_{w}:$ キャナル中の水の流速

$\gamma_{w}$ : 水の比重, $\mu_{w}$ : 水の粘性係数

\section{3. 岩石内の熱の伝導について}

次の基礎式が成立する（第 2 図）。 


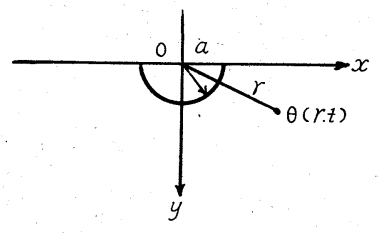

2 図

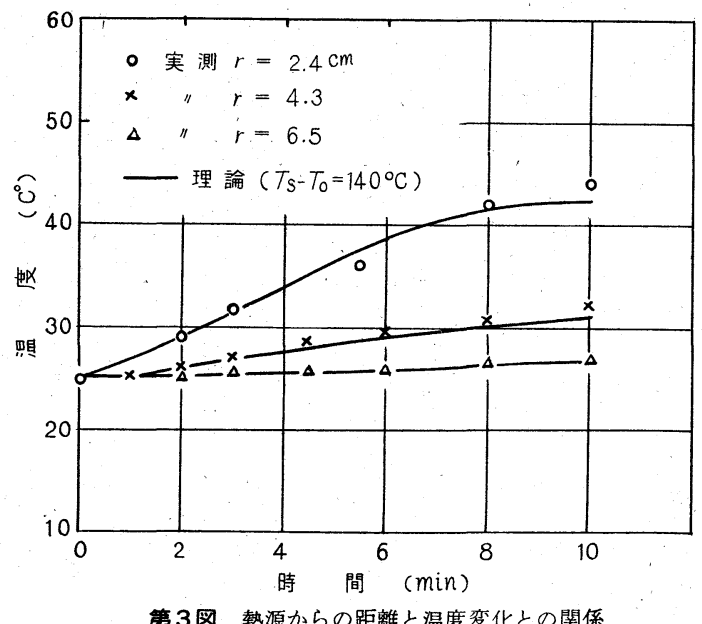

第3図熱源からの距離と温度変化との関係

$\frac{\partial \theta}{\partial t}=\xi\left(\frac{\partial^{2} \theta}{\partial x^{2}}+\frac{\partial^{2} \theta}{\partial y^{2}}\right)$

$\theta$ : 温度, $t$ : 時間, $C$ : 岩石の比熱, $\rho$ : 岩石密度 半径 $a$ の半円状に加熱源を設定し, 座標原点から $r$ の 距離にある点のある時間 $t$ における温度を $\theta(r, t)$ と すると,

$$
\begin{aligned}
\theta(r, t)= & \frac{1}{2 \xi t} \exp \left(-\frac{r^{2}}{4 \xi t}\right) \\
& \int_{0}^{\infty} \theta_{0}(R) \exp \left(-\frac{R^{2}}{4 \xi t}\right) I_{0}\left(\frac{R r}{2 \xi t}\right) R \cdot d R \cdots(13)
\end{aligned}
$$

$\theta_{0}(R)$ 源点から $R$ の距離の熱源単位面積当たりの温 度，I。第二種ゼロ階ベッセル関数。

境界条件として

$$
\begin{array}{cl}
0<R<a \text { のとを } & \theta_{0}(R)=\theta_{0}=\text { 一定 } \\
R>a & \theta_{0}(R)=0
\end{array} \quad \ldots \ldots \text { (14) }
$$

とすると，最終的に次式が求まる

$$
\begin{array}{r}
\theta(r, t)=T_{0}+\left(T_{s}-T_{0}\right) \exp \left(-\frac{r^{2}+a^{2}}{4 \xi t}\right) \\
\left\{1-\sum_{k=1}^{\infty}\left(\frac{a}{r}\right)^{k} I_{k}\left(\frac{a r}{2 \xi t}\right)\right\} \cdots
\end{array}
$$

ただし $T_{0}$ : 岩石の初温度, $T_{s}:$ 加熱温度

$20 \times 20 \times 20 \mathrm{~cm}$ 花崗岩立方体で一点を加熱し, 熱源 よりある距離はなれた所の温度を実測したのを第 3 図に 示してらる。理論式による曲線とよく一致している。

\section{4. 熱応カについて}

第 4 図のようなコア資料を(初温度 $T_{0}$ )一定温度 $\left(T_{s}\right)$ の媒質中に急に投入して急熱した場合のコア内部および 表面での温度分布を求める。コア内の熱伝導の式は

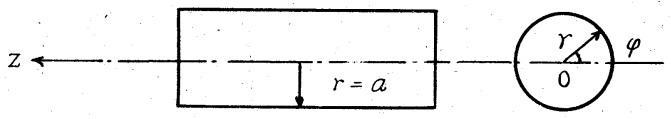

4 図

$$
\rho C \frac{\partial T}{\partial t}=\lambda\left(\frac{\partial T}{\partial r^{2}}+\frac{1}{r} \frac{\partial T}{\partial r}\right)
$$

コア表面での熱伝達の条件式としては

$$
\begin{aligned}
& r=a \text { で } \quad \lambda \frac{\partial T}{\partial r}=\mu\left(T_{s}-T\right) \\
& r=0 \text { (中心) } \quad \frac{\partial T}{\partial r}=0 \quad \cdots \cdots
\end{aligned}
$$

初期条件として $t=0 て ゙ \quad T=T_{0} \quad \cdots \ldots \ldots \ldots$ (19) ただし $\rho$ :岩石密度, $C$ : 岩石比熱, $\lambda$ :岩石熱伝導率 $\mu:$ コ表面における熱伝達率

上式を解くと, 円柱内温度分布式吕次のよ5に求まる。

$$
\begin{aligned}
T= & T_{s}-2\left(T_{s}-T_{0}\right) \sum_{n=1}^{\infty} \frac{\beta J_{0}\left(p_{n} \frac{r}{a}\right)}{\left(p_{n}^{2}+\beta^{2}\right) J_{0}\left(p_{n}\right)} \\
& \quad \exp \left(-p_{n}^{2} \frac{\lambda}{\rho_{C} a^{2}} t\right) \cdots \cdots \cdots \cdots \cdots
\end{aligned}
$$

ただし $\beta=\frac{\mu a}{\lambda}$ (Biot 係数)

$J_{0}$ は第一種ゼロ階のベッセル関数, $p_{n}$ は $p_{n} J_{1}\left(p_{n}\right)=$ $\beta J_{0}\left(p_{n}\right)$ 根である。 $J_{1}$ は第一種 1 階のべッセル関数

コアの表面および中心において最大応力值を呈する円 周応力 $\sigma_{y}$ 計算すると次のよ5になる。

$$
\begin{aligned}
\sigma_{y}= & \frac{2 E \alpha\left(T_{s}-T_{0}\right)}{1-\nu} \sum_{n=1}^{\infty}\left[\frac{\beta}{p_{n}\left(p_{n}^{2}+\beta^{2}\right) J_{0}\left(p_{n}\right)}\right. \\
& \left.\left\{p_{n} J_{0}\left(p_{n} \frac{r}{a}\right)-\frac{a}{r} J_{1}\left(p_{n} \frac{r}{a}\right)-J_{1}\left(p_{n}\right)\right\}\right] \\
& \exp \left(-p_{n}^{2} \frac{\lambda}{\rho_{C} a^{2}} t\right) \ldots \ldots \ldots \ldots \ldots \ldots \ldots \ldots \ldots \ldots \ldots
\end{aligned}
$$

この式で $r=a$ とおけば, コア表面での熱応力, $r=$ 0 とおけばコア中心での熱応力が求まる。

直径 $23 \mathrm{~mm}$, 長さ $490 \mathrm{~mm}$ のコア試料 (砂岩) の中心 に熱電対を挡入し, これを $500{ }^{\circ} \mathrm{C}$ の電気炬内に急に入れ その中心温度を実測した。その結果を第 5 図に示してい る。なお, 式(20)による理論曲線も示しているが，よく 致するとみなすととがでをる。したがって式(21)を用いて 具体的にコア表面の熱応力を求めてみると, 第 6 図のよ らになる。乙れは縦軸に無次元熱応力 $\frac{(1-\nu) \sigma}{E \alpha\left(T_{s}-T_{0}\right)}$ をと っており,横軸に無次元時間 $\tau=\frac{\lambda}{\rho C a^{2}} t$ をとっている。

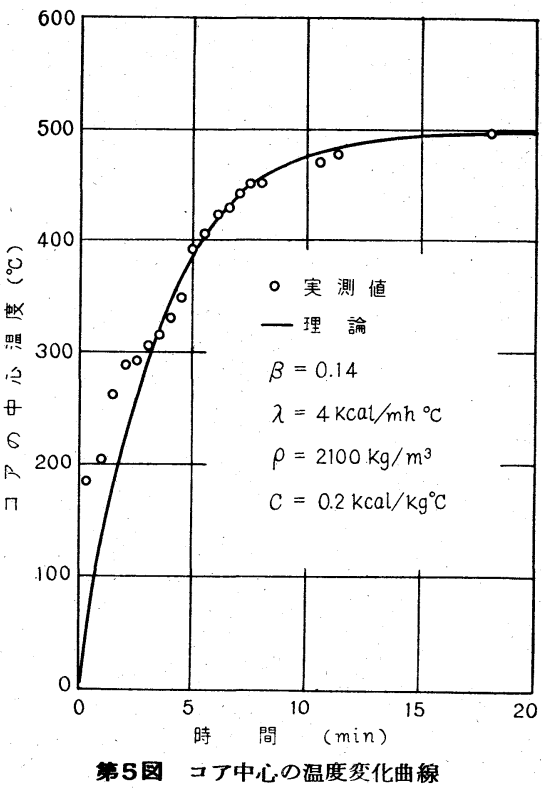

$175<15>$

Vol. 84 No. 959 ('68-3) 


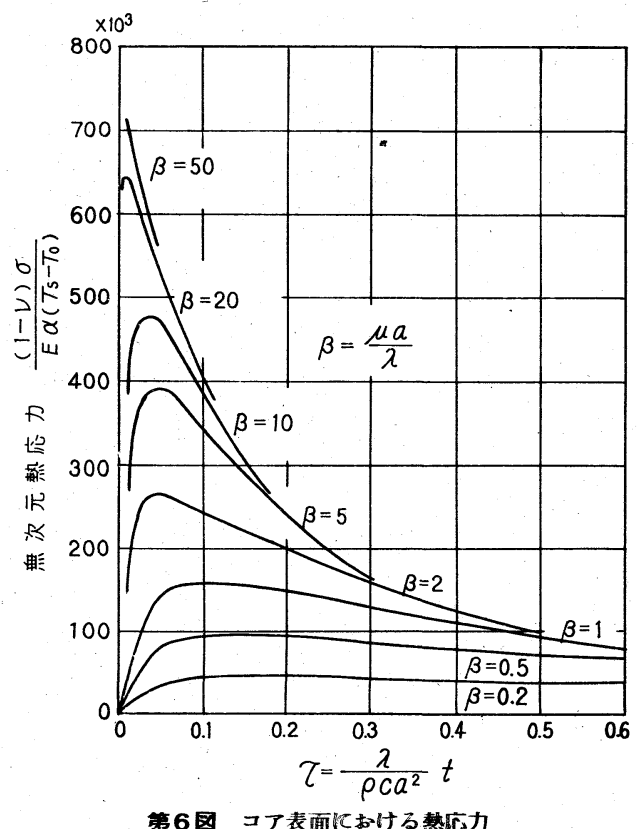

\section{5. むすび}

サーモドリルを試作しそれによる岩石の熱破壊試験を 行ならとともに, その基礎研究として, 岩石内の熱伝導 と, 熱応力を理論解析し, かつ実験でチェックしながら, 破壊メカニズムを考察した。上に導かれた実験結果と諸 式から，次のととがわかる。

（1）岩石の熱破壊を行ならためには，ただ岩石を加熱 するだけでは不十分である。

（2）熱応力による破壊を利用しょらと思えば， B i ot 係数がなるべく大をくなるよらな加熱方式をとらねばな らない。

(3) したがって加熱は火炎ジェットによらなければな らない。火炎シェット噴流ではBiot 係数 $\beta=10 \sim 30$ 程度となるので, 発生する熱応力は非常に大きい。

(4) サーモドリルの設計では，したがってジェット速 度ができるだけ大きくなるよらな設計でなければならな h。

（5）熱破壊する場合は，熱伝導率の高い岩石よりも， 低い岩石の方が好をしい。

(6) 線膨張係数の大きい岩石任ど熱破壊されやすい。

（7）熱応力は熱衝撃の瞬間に大をく，時間の経過とと もに急激に減少する。

\title{
1110 岩石の線膨張係数について
}

\author{
東京大学工学部助教授・工博 外 尾 善 次 郎(正会員) \\ 東京大学工学部助手 $\bigcirc 大$ 村 昭 士(正会員)
}

\section{1. まえがき}

熱応力を利用した岩石の熱破壊に大をな影響を与える のは，その岩石のヤング率と線膨張係数である。その岩 石の線膨張係数の温度による変化を知らなければ発生す る熱応力の大きさは計算できないし，またその岩石の線 膨張係数が加熱温度の上昇によって，どのような変化を 示すかを知ることによって，その岩石の熱破壊に対する 強度を推定するととがでさる。数種類の岩石について加 熱温度を上昇させた場合の線膨張係数の変化を実測し， さらに反覆加熱を行なった場合の履歷を求めた。

\section{2. 実験装置および実験方法}

第 1 図に実験装置を示している。電気炬 B の中に長さ 約 $13 \mathrm{~cm}$, 直径約 $2.5 \mathrm{~cm}$ の岩石試料 $\mathrm{A}$ を入, その熱膨 張による伸びを，1 端を固定し G，他端を自由に摺動し

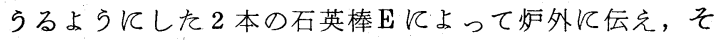
の伸びをダイヤルゲージIで測定する。

電気炬の中には素焼の筒 Cが入っており，乙の中にア ルミナディスクDを支えとして試料を横をえている。

機械的ショックやその他熱膨張によらない見掛け上の 変位が生ずる恐れがあり，またヒステリシス測定のため に最少限の復元力を与える必要があり，500 g の錘り を滑車と糸で吊り下げている。高温時には炉熱によって 固定側マグネットベース $\mathrm{G}$ や変位測定用ゲージ等が影響 をらけるため, 間にアスベスト板 $\mathrm{F}$ を立て, さらに一定 量の風を送風してI および Jが一定温度を示すようにし ている。

ダイヤルゲージにあらわれる指示值は，岩石試料の伸

$176<16>$
びと石英棒の伸びとが合計されたものとなる。したがっ て, 岩石試料の伸びはダイヤルゲージの示す值から, 石 英棒の伸びを差し引く必要がある。

炬の両側端は多少温度低下をきたすため, その影響の ない中心部に岩石試料をおいている。

線膨張係数 $(\alpha)$ は，一般に次式で示すととができる。

$$
\alpha=\frac{\Delta l}{l\left(T_{2}-T_{1}\right)}
$$

$l$ は岩石のもとの長さ, $\Delta l$ は温度が $T_{1}$ から $T_{2}$ へ変化 した場合の伸びである。

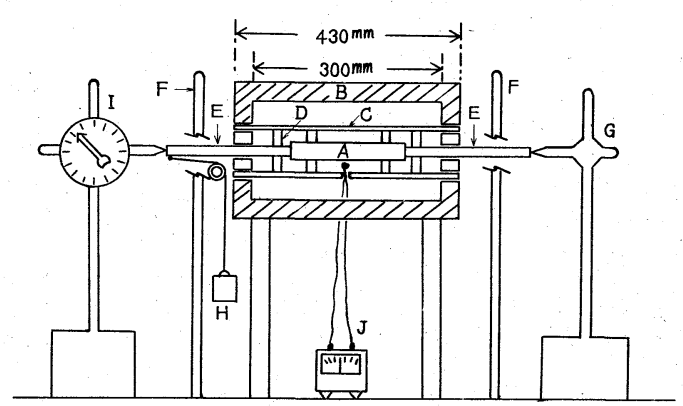

A：岩石試料 B：カンタル線環状疤 C : 素焼円筒 D：アルミナ ディスク E : 変位伀達用石英棒 $\mathrm{F}$ : 熱シール用アスペスト板 $\mathrm{G}$ : 固定側マグネットベース $\mathrm{H}$ : 復元力発生重錘 I : 変位測定用 ダイヤルダーシ J : 試料温度測定用C A 熱電対

第 1 図実験装置 